https://doi.org/10.18485/iipe_euchanges.2021.ch8

\title{
THE GLOBAL STRATEGY FOR THE FOREIGN AND SECURITY POLICY OF THE EUROPEAN UNION AND THE SECURITY OF THE REPUBLIC OF SERBIA
}

\begin{abstract}
Branko KRGA ${ }^{1}$
Abstract: The subject of the analysis of this paper is the consideration of the important views presented in the document 'Global Strategy for the Foreign and Security Policy of the European Union' (hereinafter: the EU Global Strategy) from June 2016 and their impact on the security of the Republic of Serbia. The research aims to point out the correlation of the provisions of the EU Global Strategy, their application in practice, and the positive and negative effects on the security of the Republic of Serbia. The general hypothesis of this research is: The global strategy of the EU can have a significant impact on the security of the Republic of Serbia, but so far it has not been practically realized to the possible extent. During the preparation of this text, the historical, comparative and content analysis methods were used as research methods, and in a certain sense, modelling, that is, the search for a way for the European Union to have a positive effect on the security of the Republic of Serbia. The research has shown that this topic is necessary for at least three reasons. First, the European Union has an indisputable influence on the security and defense of the Republic of Serbia, either positively or negatively. Second, the Republic of Serbia stated its position on security issues in the new 'National Security Strategy of the Republic of Serbia' (hereinafter: the RS NB Strategy) from December 2019, so it is important to see how similar or different this document is from the EU Global Strategy. Third, the latest challenges, risks and security threats of many countries show that in a certain crisis, there is a possibility of the practical influence of global and regional organizations in overcoming security problems in certain nation-states.

Keywords: global strategy, national security strategy, European Union, Republic of Serbia, security challenges, risks and threats.
\end{abstract}

${ }^{1}$ Full professor, retired colonel general, E-mail: b_krga@academyofdiplomacy.net 


\section{INTRODUCTION}

The debate on the relationship between the EU and Serbia has been going on for decades. This is, in a way, normal, considering that Serbia is located in Europe and aspires to join that integration. Thus, Ivica Dačić, Minister of Foreign Affairs at the time of the adoption of the EU Global Strategy, states in the introduction to that document: 'The world, and thus the European Union and the Balkan region, which has a very important role in the overall security of the EU, are currently undergoing numerous temptations and major challenges such as pandemics, the migrant crises, terrorism, radicalism, extremism, religious fanaticism, the security of energy supply, climate change, etc. Serbia is firmly determined to contribute to combating threats at the regional, European, and global levels, in cooperation with partners, in the world, and above all, the EU. Serbia contributes significantly to the EU's Common foreign, security and defense policy by participating in the EU and UN peacekeeping missions, and in relation to the population numbers, it ranks first in the region and eighth in Europe.In the challenges of the migrant crisis, Serbia has borne a heavy burden proving to be one of the most reliable partners of the EU and a country that fully respects the valid international conventions, the rights of vulnerable groups, and the EU value system. It is of the utmost importance to preserve the stability of the region, and Serbia sees this as one of its basic priorities, to which it is deeply committed. We are very pleased that our efforts have been recognized by European partners.

The message the EU has sent through the Global Strategy regarding our region, i.e., that a credible enlargement policy is a strategic investment in Europe's security and prosperity and that it will continue to be based on a clear, strict and consistent accession process, is an additional encouragement in the implementation process of our strategic foreign policy goal - full membership in the EU' (The Global Strategy for Foreign and Security Policy of the European Union, 2016, p. 5).

The relationship between international integration and a state can be viewed in different ways. It seems appropriate if we compare the most important documents that deal with the current topic, and then analyse the practical action, as well as, the possible optimal model of cooperation. Therefore, in this paper, the following units will be considered: (1) the EU Global Strategy and the National Security Strategy of the Republic of Serbia: similarities and differences; (2) Experiences from the practical influence of the EU on the security of the Republic of Serbia: positive and negative 
examples; and (3) A possible model for the optimal positive impact of the EU on the security of the Republic of Serbia.

\section{THE EU GLOBAL STRATEGY AND THE NATIONAL SECURITY STRATEGY OF THE REPUBLIC OF SERBIA: SIMILARITIES AND DIFFERENCES}

The analysis of the similarities and differences of such important documents must necessarily begin with a presentation of the essence of both strategies, as well as their relationship regarding some important issues. As for the EU Global Strategy, its essence can be seen in the following paragraphs.

In her introductory speech, Natalie Tocci, an Italian professor, points out: 'The EU Global Strategy, presented in June 2016 by the High Representative of the Union for Foreign Affairs and Security Policy and Vice President of the European Commission Federica Mogherini, sets out the essential interests and principles of global engagement. The strategy can explain what the EU stands for and expects to achieve in the world.

In a world that is increasingly interconnected, opposed and complex, we need a strategy that gives the Union a sense of common direction. The EU must act united on the world stage in order to provide security to its citizens, preserve our interests and represent our values.

The EU Global Strategy aims to provide a shared vision of how the Union can realize its global ambitions - from our core interests and principles of engagement to different geographical regions and policy areas. We must be united internally around security and defence and take responsibility in the regions in our neighbourhood to promote resilience and resolve conflicts and crises.

The Strategy is particularly focused on our immediate neighbourhood, bearing in mind the significant challenges to our own security, as well as to global stability, that arise there. It strives for even closer cooperation with partners than before in achieving our common goals'. (The Global Strategy for Foreign and Security Policy of the European Union, 2016, p. 7)

Federica Mogherini, the EU High Representative for Foreign Affairs and Security Policy at the time of the adoption of the EU Global Strategy, emphasizes: 'The purpose, even existence, of our Union has been called into question. Yet, our citizens and the world need a strong European Union, like ever before. Our wider region has become more unstable and insecure. 
The crises within and outside our borders are affecting directly our citizens' lives. In challenging times, a strong Union is one that thinks strategically, shares a vision and acts together. This is even more true after the British referendum. We will indeed have to rethink the way our Union works, but we perfectly know what to work for. We know what our principles, our interests and our priorities are. This is no time for uncertainty: our Union needs a Strategy. We need a shared vision, and common action ... "Global" is not just intended in a geographical sense: it also refers to the wide array of policies and instruments the Strategy promotes. It focuses on military capabilities and anti-terrorism as much as on job opportunities, inclusive societies and human rights. It deals with peace-building and the resilience of States and societies, in and around Europe. The European Union has always prided itself on its soft power - and it will keep doing so, because we are the best in this field. However, the idea that Europe is an exclusively "civilian power" does not do justice to an evolving reality. For instance, the European Union currently deploys seventeen military and civilian operations, with thousands of men and women serving under the European flag for peace and security - our own security, and our partners. For Europe, soft and hard power go hand in hand' (The Global Strategy for Foreign and Security Policy of the European Union, 2016, pp. 9-10).

On the other hand, regardingthe essence and character of the RS NB Strategy is stated: 'The National Security Strategy of the Republic of Serbia is the highest strategic document whose implementation protects national values and interests of the Republic of Serbia from security challenges, risks and threats in all areas of social life. Its starting points are the preservation of sovereignty and territorial integrity, military neutrality, care for the Serbian people outside the borders of the Republic of Serbia, European integration and an efficient rule of law ... The National Security Strategy fully reflects the Republic of Serbia's commitment to general civilizational and moral values, respect for its state-building tradition, the rule of law, social justice, democracy, human and minority rights and freedoms, economic progress, cooperative security and comprehensive international cooperation. The commitments expressed in this document express especially the readiness of the Republic of Serbia to actively participate in the processes of cooperation and joint action with other states and subjects of international relations in building and improving national, regional and global security' (The National Security Strategy of the Republic of Serbia, 2019, p. 1). 
Both analysed documents contain views on security issues, i.e, challenges, risks and threats. The EU Global Strategy states: 'The Security of our Union. The EU Global Strategy starts at home. Our Union has enabled citizens to enjoy unprecedented security, democracy and prosperity. Yet today terrorism, hybrid threats, economic volatility, climate change and energy insecurity endanger our people and territory. An appropriate level of ambition and strategic autonomy is important for Europe's ability to promote peace and security within and beyond its borders. We will therefore enhance our efforts on defence, cyber, counterterrorism, energy and strategic communications. Member States must translate their commitments to mutual assistance and solidarity enshrined in the Treaties into action. The EU will step up its contribution to Europe's collective security, working closely with its partners, beginning with NATO' (The Global Strategy for Foreign and Security Policy of the European Union, 2016, p. 23).

The RS NB Strategy handles the essential security problems as follows: 'Circumstances that contribute to the emergence of challenges, risks and threats to security at the global level are, above all, large differences in terms of economic and cultural development, which result in poverty and social vulnerability of the huge part of the population, which causes the emergence of negative demographic and socio-psychological phenomena. Regional and local conflicts, ethnic and religious extremism, terrorism, organized crime, the proliferation of weapons of mass destruction, illegal migration, hybrid threats, cyber threats, limited availability of natural resources, including water, food, energy and raw materials, and climate change and degradation of the natural environment, threaten the stability of individual countries and entire regions, as well as global security.

The general state of security in the world is significantly endangered by gross violations of the United Nations Charter and generally accepted norms of international law, and especially interference in the internal affairs of sovereign states, as well as the concept and practice of preventive attack and military interventionism. Of particular concern is the tendency of straining relations between the great powers, conditioned by competition for the realization of their opposing interests and the change of existing spheres of influence. In such circumstances, the risk of a global military conflict, although significantly reduced, cannot be completely ruled out. The biggest threats at the international level, in the long run, will continue to be international terrorism, organized crime, strengthening political and religious extremism, the migrant crisis and mediation conflicts' (The National Security Strategy of the Republic of Serbia, 2019, pp. 2-3). 
Both documents emphasize the importance of an integrated approach to security issues. Thus, the EU Global Strategy states: 'An Integrated Approach to Conflicts. When violent conflicts erupt, our shared vital interests are threatened. The EU will engage in a practical and principled way in peace-building, and foster human security through an integrated approach. Implementing the "comprehensive approach to conflicts and crises" through a coherent use of all policies at the EU's disposal is essential. But the meaning and scope of the 'comprehensive approach' will be expanded. The EU will act at all stages of the conflict cycle, acting promptly on prevention, responding responsibly and decisively to crises, investing in stabilisation, and avoiding premature disengagement when a new crisis erupts. The EU will act at different levels of governance: conflicts such as those in Syria and Libya have local, national, regional and global dimensions which must be addressed. Finally, none of these conflicts can be solved by us alone. Sustainable peace can only be achieved through comprehensive agreements rooted in broad, deep and durable regional and international partnerships, which the EU will foster and support' (The Global Strategy for Foreign and Security Policy of the European Union, 2016, pp. 15-16). When the problems of security and defence are elaborated, similar views are expressed: 'As Europeans, we must take greater responsibility for our security. We must be ready and able to deter, respond to, and protect ourselves against external threats. While NATO exists to defend its members - most of which are European - from external attack, Europeans must be better equipped, trained and organised to contribute decisively to such collective efforts, as well as to act autonomously if and when necessary. An appropriate level of ambition and strategic autonomy is important for Europe's ability to foster peace and safeguard security within and beyond its borders.

Europeans must be able to protect Europe, respond to external crises, and assist in developing our partners' security and defence capacities, carrying out these tasks in cooperation with others. Alongside external crisis management and capacity-building, the EU should also be able to assist in protecting its Members upon their request, and its institutions' (The Global Strategy for Foreign and Security Policy of the European Union, 2016, p. 25).

The RS NB Strategy emphasizes: 'Integrative processes in the field of security, as well as growing political, economic and cultural cooperation, significantly reduce the risks of state conflicts, as well as the possibility of uncontrolled crises and transfer of conflicts from one area to another. However, the world is still faced with numerous, multi-determined security 
challenges, risks and threats that need to be addressed in a timely and adequate manner. Given the dynamic changes in international relations, security challenges, risks and threats are changing the character and forms of expression' (The National Security Strategy of the Republic of Serbia, 2019, p. 2 ).

The RS NB Strategy also states the following: 'The European Union and/or its member states face the need to address a number of complex issues, such as the threat of terrorism, asylum policy and migration management, the financial crisis and the eurozone public debt crisis, which demands the institutional response of the European Union and its Member States to all mentioned challenges' (The National Security Strategy of the Republic of Serbia, 2019, p. 3).

The analysis of the similarities and differences of two documents that deal with approximately the same issues can be best realized if the views on some essential issues are compared. In this case, views on several risks and threat challenges will be presented.

The EU Global Strategy addresses the 'commitments to mutual assistance and solidarity and includes addressing challenges that have both internal and external dimensions, such as terrorism, hybrid threats, hightech and energy security, organized crime and external border management'(The Global Strategy for Foreign and Security Policy of the European Union, 2016, p. 26). The fight against terrorism, high-tech security and energy security are discussed in greater detail (The Global Strategy for Foreign and Security Policy of the European Union, 2016, pp. 25-29).

On the other hand, The RS NB Strategy states significantly more challenges, risks and threats, such as armed aggression against the Republic of Serbia, separatist aspirations, the illegally unilaterally declared independence of the territory administratively covered by the Autonomous Province of Kosovo and Metohija, armed rebellion, terrorism, the proliferation of weapons of mass destruction, ethnic and religious extremism, intelligence activities of foreign entities, organized crime, drug addiction, mass illegal migration, problems of economic development of the Republic of Serbia, problems of demographic development of the Republic of Serbia, epidemics and pandemics of infectious diseases, energy security of the Republic of Serbia, the unfinished process of delimitation of the states of the former SFRY, natural disasters and technical-technological accidents, climate change, high-tech crime and endangerment of information and communication systems. In addition to the above-mentioned, there are other security challenges, risks and threats that can have a significant impact, such 
as corruption and misuse of new technologies and scientific achievements, genetic engineering, medicine, meteorology and other scientific fields. (The Global Strategy for Foreign and Security Policy of the European Union, 2016, pp. 10-14).

\section{Similarities between the EU Global Strategy and The RS NB Strategy}

- Both strategies address the issue of security at the highest level of importance;

- Advocating for peace and cooperation runs through both documents;

- These documents point out the importance of an integrated and cooperative approach to the security, and cooperation of various entities in that field.

\section{Differences between the EU Global Strategy and the RS NB Strategy}

- The EU Global Strategy, in addition to security issues, deals equally with foreign policy issues, while the RS NB Strategy mainly deals with national security issues;

- The EU Global Strategy addresses significantly fewer challenges, risks and threats than the RS NB Strategy;

- The EU Global Strategy does not treat Serbia in particular, as well as other countries in Southeast Europe. Our space is not in the priority of the EU, so even in the operational plans, one cannot expect anticipation of concrete measures;

- On the other hand, the RS NB Strategy mentions the EU dozens of times.

\section{EXPERIENCES FROM THE PRACTICAL INFLUENCE OF THE EU ON THE SECURITY OF THE REPUBLIC OF SERBIA: POSITIVE AND NEGATIVE EXAMPLES}

The practical operation of some institutions often deviates from the positions defined in strategic- doctrinal and normative documents. Regardless of declarative determinations, practical action is still the best indicator of the essence of the existence and functioning of some subjects. In this regard, the following views set out in the EU Global Strategy deserve attention: 'The European Union will promote peace and guarantee the security of its citizens and territory. Internal and external security are ever 
more intertwined: our security at home depends on peace beyond our borders. ... The EU will promote a rules-based global order. We have an interest in promoting agreed rules to provide global public goods and contribute to a peacefuland sustainable world. The EU will promote a rulesbased global order with multilateralism as its key principle and the United Nations at its core. ...In a more contested world, the EU will be guided by a strong sense of responsibility. We will engage responsibly across Europe and the surrounding regions to the east and south. We will act globally to address the root causes of conflict and poverty, and to promote human rights. The EU will be a responsible global stakeholder, but responsibility must be shared. Responsibility goes hand in hand with revamping our external partnerships. In the pursuit of our goals, we will reach out to states, regional bodies and international organisations. We will work with core partners, like-minded countries and regional groupings. We will deepen our partnerships with civil society and the private sector as key players in a networked world' (The Global Strategy for Foreign and Security Policy of the European Union, 2016, pp. 13-14).

The activities of the Union, as emphasized in the EU Global Strategy, are indicated by the following defined priorities: security of our Union; state and social resilience in our east and south; an integrated approach to conflicts; cooperative regional orders; and global governance for the 21st century (The Global Strategy for Foreign and Security Policy of the European Union, 2016, pp. 15-16).

In the EU's response to the security challenges, risks and threats that our country is facing, there are some positive but also unfavourable examples. Positive examples are reflected, above all, in the fact that the EU is declaratively committed to peace and civilized problem solving within the EU and in neighbouring areas. Negative examples relate to the experiences that have come to light in recent years when it comes to attitudes and practices regarding the threat to the territorial integrity of Serbia, then the treatment of the world economic crisis, terrorism, control of illegal emigration, and most recently, the attitude towards the fight against the pandemic. These attitudes and practices indicate that our country cannot fully rely on the EU in terms of preserving its security and international position.

Certainly, the most negative example refers to the fact that the majority of EU members recognized the illegally unilaterally declared independence of the territory administratively covered by the Autonomous Province of Kosovo and Metohija, and this problem is rightly presented in the RS NB 
Strategy as a first-order security problem. If the EU is conceived as a kind of security project, then the structures of that integration should have understood that endangering the key national interest of a candidate country for membership must have certain negative consequences for the members of the Union themselves.

In that sense, the former Minister of Foreign Affairs of the FRY, Živadin Jovanović, notes: 'Macron and Merkel reiterate that it is time for Europe (EU) to turn to itself, but regarding Kosovo and Metohija, they continue the destructive policy imposed by the United States in 1999, which forced it to participate in illegal armed aggression against Serbia (FRY). Using a combination of threats, blackmail and flattery, the leading European countries are trying to drag Serbia into the scenario of creating another Albanian state on a part of its territory, to draw new international borders that divide the Serbian people. They do that, above all, in order to satisfy their selfish geopolitical interests ...' (Jovanović, 2018, p. 752).

A similar assessment is made by Hannes Hofbauer: 'Military intervention as a continuation of politics has long gained a place in the politics of Brussels ... With the proclamation, and soon after, the recognition of Kosovo's independence from Washington, Berlin, and Paris in February 2008, the very international legal basis of the post-war order was shaken, both militarily and politically, which meant the end of the post-war era' (Hofbauer, 2012, p. 18; 28).

At the Bled Forum in 2020, the Prime Minister of Hungary, Viktor Orbán, mentioned the importance of Serbia for European security. Orbán pointed out that 'without EU enlargement and Serbia's accession to the European Union, it is not possible to create a complete European Union security infrastructure' (Politika, 2020). However, this basically correct position does not seem to find wide support in EU structures.

A well-known American intellectual, Noam Chomsky, expressed his views on many issues related to the crisis in the former Yugoslavia. He also deserves attention for pointing out the basic causes of the NATO attack on the FRY, referring to Strobe Talbot, the US Deputy Secretary of State in 1999. In his views, Chomsky notes: 'He recently wrote a preface to a book of his communications director, John Norris. In that preface, he says that it is a book that we should read if we want to understand how the top of the Clinton administration hasthought. He says the real purpose of the war had nothing to do with Kosovo Albanians. The war happened because Serbia did not implement the required social and economic reforms, which means 
that it was the last part of Europe that did not submit to the neoliberal programs led by the United States ...' (Čomski, 2018, p.201).

In addition to bare geopolitical interests and the desire to affirm NATO, what Noam Chomsky states is the essential reason for the 1999 aggression. Elementary logic raises the question of whether these could have been the real reasons for the aggression against an old European country at the end of the 20th century, which was so strongly supported and participated in by many EU members. It is worth remembering all the hoaxes and untruths that came from certain EU countries (insinuations about the conflict in the village of Račak, accusations against our country for Operation 'Horseshoe', which did not exist, etc.). It would be good for EU structures to explain to the public how much they had spent and why they gave up the proclaimed peace policy and many of their own values in practice due to the disintegration (breakup of Yugoslavia), the aggression against the FRY in 1999 and recognition of Kosovo's independence. This is all the more strange given the assessments of the character of the EU.

Thus, Professor David Dašić states: 'The European Union is the greatest project of peace (Pax Europaea) in the history of mankind, bigger than the golden age of the Roman Empire in the first and second centuries of the new era (Pax Romana)' (Dašić, 2013, p. 563).

EU High Representative for Foreign Affairs and Security Policy, Josep Borrell, made a similar assessment of the importance of the EU: 'If we do not stabilize the Balkans, it will be difficult to consider ourselves a geopolitical force, because no one else will do it, only Europeans' (BETA, 2020).

In the EU Annual Report on Serbia for 2020, only the fight against corruption and organized crime is critically mentioned in the range of security problems, and more affirmative views on Serbia's attitude towards migrants are presented. Positions are expressed about Kosovo (with an asterisk) only in the context of the normalization of relations with Serbia (as if they were two sovereign states). It is also mentioned that Serbia continues its strategic partnership with numerous countries, with special emphasis on China (around the fight against the pandemic) and Russia (military-technical cooperation), and the United States (relocation of the Serbian embassy to Jerusalem) (Delegacija Evropske Unije u Republici Srbiji, 2020).

It would be in the wider interest of the EU to confirm the proclaimed positions on security in practice, among other things, when it comes to energy policy and especially enlargement policy: 'If the EU is, among other things, a major security project, then it is surprising that it takes so long to admit countries that are in a security risk region. The structures of the EU 
and its members have already spent significant funds in calming the Balkan crisis, so the admission of those countries to membership and their behaviour in accordance with European values would probably be in the interest of the EU members themselves. It would be especially unfavourable if the conditioning of the Republic of Serbia continues, which was not applied on other countries recently admitted to the EU' (Krga, 2017, p. 160).

Serbia, for its part, strongly emphasizes its commitment to EU membership, contributes to solving common European problems, such as migrants, agreed that the EU would be the bearer of technical negotiations on solving the problems related to Kosovo and Metohija, participates in multinational operations, in addition to the United Nations, and the EU, etc. The EU Annual Report on Serbia for 2020 states: 'Serbia is in line with 60\% of the positions of the Common Foreign and Security Policy of the EU in 2019 and should intensify efforts to gradually harmonize its foreign and security policy with the Common EU policy in the period until accession' (Delegacija Evropske Unije u Republici Srbiji, 2020).

Regarding these integrations, Professor Milomir Stepić notes: 'EU (and NATO) membership cannot be a rationally determined "higher goal" or a "far-sighted decision", as the identity, (geo) political, economic and other harms will be undoubted and priceless. The "amputation" of Kosovo and Metohija, and the further probable violation of the territorial integrity of Serbia, are the most concrete, but still only a partial price. The overall postYugoslav ultimate condition for the Serbian factor in the Balkans is complete national disintegration for the sake of questionable inclusion in EuroAtlantic supranational integrations' (Stepić, 2019, p. 125).

There is no doubt that in the structures of the EU when it comes to the attitude towards the security of Serbia, there are clear differences between the general declarative views on the importance of peace and cooperation and the practical moves of individual members and structures of that community. This is certainly not essentially in favour of the security of either the EU or Serbia. Due to such practical behaviour of certain EU institutions, it is imperative for Serbia to realize its own security problems mostly within the national framework. This is also noted by Mile Bjelajac: 'Therefore, the states and their statesmen in the 21st century have the obligation to assess security challenges together with the security forces, and with comprehensive knowledge in this area ensure sovereign power over the entire territory and protection from new attacks from outside and inside' (Bjelajac, 2010, p. 312). 


\section{A POSSIBLE MODEL OF OPTIMAL POSITIVE INFLUENCE OF THE EU ON THE SECURITY OF THE REPUBLIC OF SERBIA}

Given the real existence of the EU, with numerous institutions, as well as the fact that Serbia is oriented towards joining that integration, it is justified to consider a model of its optimal positive impact on the security of our country, regardless of the views expressed in the previous part.

Experiences from the integration process so far indicate that it would be good for Serbia to get rid of the obsession that 'the EU has no alternative'. The alternative can come without Serbia's influence for the following reasons: first, the EU may conclude that it will not expand further; second, Serbia may be given such conditions that it will not want or be able to meet; and third, the EU may disintegrate, as the most prominent representatives of that integration occasionally warn. Therefore, the alternative to EU membership can simply be forced, and that is, practically, what we have now, an independent, but better organized, legal and prosperous state, which cooperates with many foreign factors.

In such conditions, the following elements are important for the formation of the model of the positive influence of the EU on the security of Serbia: (1) defining the desirable attitude of the EU towards the security of Serbia in political, strategic-doctrinal and normative documents; (2) reaching an agreement on practical cooperation between the EU and Serbian bodies in terms of neutralizing negative challenges, risks and threats that affect the security of Serbia, but also the members of the Union; and (3) exchange of experiences and harmonization of normative positions, organizational solutions, staff training and equipping of individual organizations that practically solve security issues.

Based on the above, the model could contain the following: 'the EU in its strategic-doctrinal and operational documents treats Serbia and other candidate countries as partners in solving challenges, risks and threats;it affirms specific forms of cooperation with elements of Serbia's national security system.On the other hand, Serbia is taking the necessary measures to resolve the issue of national security, relying on the EU to the agreed extent, engaging its capacities, thus contributing to the security of the Union as a whole'.

It is an optimal model and perhaps a little idealistic.But without this or a similar vision, it is difficult to assume that, in the future, a concrete correlation of a positive impact on the security of the EU, and above all Serbia, could be achieved. 


\section{CONCLUSION}

The presented facts indicate that, so far, no special and necessary conditions have been created for the optimal positive influence of the EU on the security of the Republic of Serbia. At the same time, if there was goodwill of EU members, there would be possibilities for such a form of correlation, which would be expedient for both the EU and Serbia.

If something changes in that direction in the meantime, it will take a long time to establish the necessary practical and efficient relations. This problem is complicated by the fact that the further development and even survival of the EU are extremely problematic because the members of that integration cannot agree on some essential issues. This means that at least three options will operate in the next period: (1) EU reforms in the direction of federal regulation; (2) reforms towards a confederate model; (3) the option of partial or complete disintegration of the EU will always be present. Many point to these problems, and Richard Haas observes: 'As far as the European Union is concerned, there is obviously a need to reform it' (Haas, 2017, p. 279).

Given the situation in the EU and its attitude towards Serbia, the most important security issue related to the crisis around Kosovo and Metohija, our country should treat it in a relatively new way. 'In resolving the KosovoMetohija crisis, according to a favourable variant, an integrated approach should be applied, which means engaging politics, diplomacy on the highest and residential basis, then, economy, elements of the national security system, culture, science, media and other potentials in several phases." Namely, a multidimensional problem, such as this Kosovo-Metohija problem, cannot be solved by only one dimension - for example, diplomacy. That is why an integrated approach is needed' (Krga\&Bjelja, 2018, p. 35).

Having all this in mind, Serbia should continue to correctly treat members and candidates for EU membership and support peace and the strengthening of national and regional security. However, given the internal problems in the EU and its previous relations with Serbia's security, our country should mainly rely on its capabilities and continue to improve and strengthen them. That will make it a more important country and more interesting for foreign factors, including EU structures.

\section{REFERENCES}

BETA (2020, September 13.). Borel: Samo Eu može da stabilizuje Balkan, retrieved from https://www.autonomija.info/borel-samo-eu-moze-dastabilizuju-balkan. 
Bjelajac, M. (2010). Diplomatija i vojska [Diplomacy and the military]. Beograd, Medija centar "Odbrana“ i Aкademija za diplomatiju i bezbednost.

Čomski, N. (2018). Jugoslavija - mir, rat i raspad [Yugoslavia - peace, war and disintegration]. Beograd, Samizdat.

Dašić, D. (2013). Diplomatija [Diplomacy] Beograd, Alters.

Delegacija Evropske Unije u Republici Srbiji. (2020). Godišnji izveštaj o Srbiji, retrieved from http:/ / europa.rs/godisnji-izvestaj-o-srbiji-2020/.

Haas, R.(2017). Svet u neredu [The world in disarray]. Beograd, CIRSD.

Hofbaues, H. (2012). Naručena istina - kupljena pravda, kolonijalizam Evropske unije [Ordered truth - purchased justice, colonialism of the European Union]. Beograd, Jasen.

Jovanović, Ž. (2018). 1244 Ključ mira u Evropi [1244 A Key to Peace in Europe]. Beograd, Beogradski forum za svet ravnopravnih i Srpska književna zadruga.

Krga, B. (2017). Strategija nacionalne bezbednosti - teorija i praksa [National Security Strategy - Theory and Practice]. Beograd, Medija centar "Odbrana“.

Krga, B.\&Bjelja, D. (2018). Integralni pristup rešavanju kosovko - metohijske krize [An integrated approach to resolving the Kosovo - Metohija crisis], Diplomatija i bezbednost, 1, pp. 31-42.

Politika (2020 September 1). Orban: Bez prijema Srbije nepotpuna bezbednost EU [Orban: Incomplete EU security without Serbia's accession].

Stepić, M. (2019). Srpski geopolitički obrazac [Serbian geopolitical pattern]. Beograd, Catena mundi.

The Global Strategy for the Foreign and Security Policy of the European Union (2016). The Ministry of Foreign Affairs of the Republic of Serbia, Institute for European Studies and Center for International and Security Affairs - ISAC Fund.

The National Security Strategy of the Republic of Serbia, (2019). Narodna skupština Republike Srbije, Službeni glasnik, 94. 